\title{
Hope, Fear, Shame, Frustration: Continuity and Change in the Expression of Coloured Identity in White Supremacist South Africa, 1910-1994
}

\section{Mohamed Adhikari}

To cite this article: Mohamed Adhikari (2006) Hope, Fear, Shame, Frustration: Continuity and Change in the Expression of Coloured Identity in White Supremacist South Africa, 1910-1994, Journal of Southern African Studies, 32:3, 467-487, DOI: 10.1080/03057070600829542

To link to this article: http://dx.doi.org/10.1080/03057070600829542

曲 Published online: 21 Nov 2006.

Submit your article to this journal $₫$

Џll Article views: 220

Q View related articles ¿

Citing articles: 11 View citing articles $\square$ 


\title{
Hope, Fear, Shame, Frustration: Continuity and Change in the Expression of Coloured Identity in White Supremacist South Africa, 1910-1994
}

\author{
MoHAMED ADHIKARI \\ (University of Cape Town)
}

This article seeks to explain the basic impulses behind coloured exclusivity in white supremacist South Africa and to elaborate on continuity and change in the processes of coloured self-definition by identifying the core attributes of coloured identity and outlining the ways in which they operated to reinforce and reproduce that identity. The central argument is that coloured identity is better understood not as having evolved through a series of transformations, as conventional historical thinking would have it and as the existing literature assumes, but as having remained remarkably stable throughout the era of white rule. It is argued that this stability derived from a core of enduring characteristics that informed the manner in which colouredness functioned as an identity during this period. This is not to contend that coloured identity was static or that it lacked fluidity, but that there were both important constraints on the ways in which it was able to find expression and sufficiently strong continuities in its day-to-day functioning for coloured identity to have remained recognisably uniform despite radical changes in the social and political landscape during this time. The principal constituents of this stable core are the assimilationism of the coloured people, which spurred hopes of future acceptance into the dominant society; their intermediate status in the racial hierarchy, which generated fears that they might lose their position of relative privilege and be relegated to the status of Africans; the negative connotations, especially the shame attached to racial hybridity, with which colouredness was imbued; and finally, the marginality of the coloured community, which severely limited their options for social and political action, giving rise to a great deal of frustration.

\section{Introduction}

The marginality of the coloured community is reflected in South African historiography, in that relatively little has been written on the history of this social group and much of what has been written either reproduces the simplistic formulations of popular racist conceptions of coloured identity or focuses narrowly on coloured protest politics and the social injustices suffered by the community. ${ }^{1}$ The existing literature largely ignores crucial questions relating

1 For the more recent studies on the history of the coloured people, see M. Hommel, Capricorn Blues: The Struggle for Human Rights in South Africa (Toronto, Culturama, 1981); R. van der Ross, The Rise and Decline of Apartheid: A Study of Political Movements Among the Coloured People of South Africa, 1880-1985 (Cape Town, Tafelberg, 1986); G. Lewis, Between the Wire and the Wall: A History of South African 'Coloured' Politics (Cape Town, David Philip, 1987); I. Goldin, Making Race: The Politics and Economics of Coloured Identity in South Africa (Cape Town, Maskew Miller Longman, 1987); R. du Pré, Separate but Unequal: The 'Coloured' People of South Africa - a Political History (Johannesburg, Jonathan Ball, 1994). 
to the nature of coloured identity, including the social and political dynamic that informed coloured exclusivity. By assuming colouredness to be either an in-bred quality that is the automatic product of miscegenation or an artificial identity imposed by the white supremacist establishment on weak and vulnerable people as part of a divide-and-rule strategy, this diverse historiography has denied coloured people a significant role in the making of their own identity. ${ }^{2}$ Les Switzer summed up the situation eloquently in 1995 when he wrote that 'South Africa's coloured community has remained a marginalised community - marginalised by history and even historians' ${ }^{3}$ The most recent scholarly volume on the subject, edited by Zimitri Erasmus, ${ }^{4}$ breaks with this pattern in focusing directly on coloured identity and not suffering from the usual coyness about broaching sensitive issues, such as racial hostility towards Africans or the sense of shame that suffuses colouredness. It does, however, lack coherence in that its narrowly focused contributions fail collectively to provide a sustained narrative or consistent interpretation of the history or nature of coloured identity.

This article aims to contribute to a more nuanced understanding of the manner in which colouredness functioned as a social identity in South African society during the era of white rule. The analysis seeks to identify the fundamental social and political impulses behind the assertion of a separate coloured identity and to investigate processes of continuity and change in its expression during this period. Attention is focused on the manner in which the marginality of the coloured community, its intermediate status in the South African racial hierarchy, its cultural affinities and the derogatory associations attached to the identity, influenced processes of coloured self-definition. By concentrating on the role that coloured people themselves played in the making of their identity and by exploring the ways in which ambiguities and contradictions within their group identity shaped their consciousness, this study seeks to elucidate complexities in coloured social experience hitherto neglected by historians.

\section{Coloured Identity in Historical Perspective}

Contrary to (now perhaps increasingly outmoded) international usage, in South Africa the term 'coloured' does not refer to black people in general. ${ }^{5}$ It instead alludes to a phenotypically diverse group of people ${ }^{6}$ descended largely from Cape slaves, the indigenous Khoisan population and other people of African and Asian descent who had been assimilated into Cape colonial society by the late nineteenth century. Being also partly descended from European settlers, coloured people have popularly been regarded as being of 'mixed race' and have held an intermediate status in the South African racial hierarchy, distinct from the historically dominant white minority and the numerically

2 For a more detailed critique of this historiography see M. Adhikari, 'Hope, Fear, Shame, Frustration: Continuity and Change in the Expression of Coloured Identity in White Supremacist South Africa, 1910-1994' (Ph.D. thesis, University of Cape Town [UCT], 2002), pp. 63-9, and M. Adhikari, 'From Narratives of Miscegenation to Post-Modernist Re-Imaginings: A Historiography of Coloured Identity' (unpublished paper, National Heritage and Cultural Studies Centre, University of Fort Hare, 2005).

3 L. Switzer, review of M. Adhikari, Let Us Live for Our Children: The Teachers' League of South Africa, 19131940 (Cape Town, UCT Press, 1993) in the Journal of African History, 36, 2 (1995), p. 338.

4 Z. Erasmus (ed.), Coloured by History, Shaped by Place: New Perspectives on Coloured Identities in Cape Town (Cape Town, Kwela Books, 2001).

5 In this article the term 'black' is used in its inclusive sense to refer to African, coloured and Indian people collectively, while 'African' refers to the indigenous Bantu-speaking peoples of South Africa.

6 Novelist, academic and literary critic, Kole Omotoso, describes the skin colour of coloured people, the most important of these phenotypical features, as varying 'from charcoal black to breadcrust brown, sallow yellow and finally off-white cream that wants to pass for white'. Cape Times, 14 January 2002. 
preponderant African population. ${ }^{7}$ There are approximately three-and-a-half million coloured people in South Africa today. ${ }^{8}$ Constituting no more than 9 per cent of the population throughout the twentieth century and lacking significant political or economic power, coloured people have always formed a marginal group in South African society. Moreover, their regional concentration is marked, with approximately 90 per cent of coloured people resident within the western third of the country, over two-thirds of all coloured people in the Western Cape, and 40 per cent in the greater Cape Town area. ${ }^{9}$ The coloured category has also generally been taken (ideologically and, in the past, legislatively) to include a number of distinct sub-groups such as Malays, Griquas, Namas and Basters. ${ }^{10}$

Although coloured identity crystallised in the late nineteenth century, the process of social amalgamation within the colonial black (in the sense of 'non-European') population at the Cape that gave rise to coloured group consciousness dates back to the period of Dutch colonial rule. It was, however, in the decades after the freeing of both the local Khoisan in 1828 (from colonial restrictions on their labour mobility) and the imported slaves in 1834-38 (with the empire-wide emancipation) that various components of the heterogeneous, but generally non-Bantu-speaking, black labouring class in the Cape Colony started integrating more rapidly and developing an incipient shared identity. This identity was based on a common socio-economic status and a shared culture derived from their incorporation into the lower ranks of Cape colonial society. ${ }^{11}$ The emergence of a fully-fledged coloured identity as we know it today was precipitated in the late nineteenth century by the sweeping social changes that came in the wake of the mineral revolution. Not only did significant numbers of Africans, especially Xhosa-speakers, start coming to the western Cape from the 1870s onwards but assimilated colonial blacks and a wide variety of African people who had recently been incorporated into the capitalist economy were thrust together in the highly competitive environment of the newly established mining towns. ${ }^{12}$ These developments drove acculturated colonial blacks to assert a separate identity in order to claim a position of privilege relative to Africans on the basis of their closer assimilation to western culture and being partly descended from European colonists. ${ }^{13}$

7 See M. Adhikari, 'Coloureds', in C. Saunders (consulting ed.), An Illustrated Dictionary of South African History (Johannesburg, Ibis Books, 1994), pp. 77-9.

8 The People of South Africa Population Census, 1996: Primary Tables - the Country as a Whole (Report No. 0301-19), p. 6; Statistics South Africa, 2000 (Pretoria, Government Publications Dept., 2001), 1.1.

9 Compare statistics in Census of the Union of South Africa, 1911 (U.G.32-1912), Annexure 1, pp. 7-11 with South African Census, 1996, p. 6.

10 The term 'Cape Coloured' is usually used to distinguish coloured people from the broader category that includes these sub-groups.

11 M. Adhikari, 'The Sons of Ham: Slavery and the Making of Coloured Identity', South African Historical Journal, 27 (1992), pp. 107-8; N. Worden, 'Adjusting to Emancipation: Freed Slaves and Farmers in MidNineteenth Century Southwestern Cape', in W. James and M. Simons (eds), The Angry Divide: Social and Economic History of the Western Cape (Cape Town, David Philip, 1989), pp. 33-4; P. Scully, 'The Bouquet of Freedom: Social and Economic Relations in the Stellenbosch District, 1870-1900' (MA thesis, University of Cape Town, 1987), pp. 11-12.

12 Adhikari, 'Sons of Ham', p. 110; W. Worger, South Africa's City of Diamonds: Mineworkers and Monopoly Capitalism in Kimberley, 1867-1895 (New Haven, CT, Yale University Press, 1987), Chapter 2; R. Turrell, Capital and Labour on the Kimberley Diamond Fields, 1871-1890 (Cambridge, Cambridge University Press, 1987), pp. 29-31, 94-104; V. Bickford-Smith, 'Commerce, Class and Ethnicity in Cape Town, 1875-1902' (Ph.D. thesis, Cambridge University, 1988), pp. 102-3, 185-8.

13 See M. Adhikari, Teachers' League, pp. 11-18, and 'Sons of Ham', pp. 95-112, for a more detailed discussion of the origins of coloured identity. For case studies of the process in Cape Town and Kimberley respectively, see V. Bickford-Smith, Ethnic Pride and Racial Prejudice in Victorian Cape Town, 1875-1902 (Cambridge, Cambridge University Press, 1995), pp. 186-209 and P. Lawrence, 'Class, Colour Consciousness and the Search for Identity at the Kimberley Diamond Diggings, 1867-1893' (MA thesis, University of Cape Town, 1994). 
Because of their marginality and the determination with which the South African state implemented white supremacist policies, the story of coloured political organisation during the period of white rule has largely been one of compromise, retreat and failure. The most consistent feature of coloured political history until the latter phases of apartheid has been the continual erosion of the civil rights first bestowed upon black people in the Cape Colony by the British administration in the mid-nineteenth century. The process of attrition started with the franchise restrictions imposed by the Parliamentary Registration Act of 1887 and the Franchise and Ballot Act of $1892 .{ }^{14}$ A spate of segregationist measures in the first decade of the twentieth century further compromised the civil rights of coloured people. ${ }^{15}$ In the 1920s and 1930s the economic advancement of the coloured community was undermined by the Pact government's 'civilised labour' policy and a number of laws designed to favour whites over blacks in the competition for employment. ${ }^{16}$ Furthermore, in 1930, the influence of the coloured vote was more than halved by the enfranchisement of white women only. ${ }^{17}$ It was during the apartheid era, however, that coloured people suffered the most severe violations of their civil rights. Their forced classification under the Population Registration Act of 1950 made the implementation of rigid segregation possible. The Prohibition of Mixed Marriages Act of 1949 and the Immorality Amendment Act of 1950 respectively outlawed marriage and sex across the colour line. Under the Group Areas Act of 1950 tens of thousands of coloured families were forcibly relocated to residential and business areas usually on the periphery of cities and towns. The 1953 Separate Amenities Act, which introduced 'petty apartheid' by segregating virtually all public facilities, also created deep resentment. After a protracted legal and constitutional battle the National Party in 1956, moreover, succeeded in removing coloured people from the common voters' roll. ${ }^{18}$

Because their primary objective was to assimilate into the dominant society, politicised coloured leaders initially avoided forming separate political organisations. By the early twentieth century, however, intensifying segregation forced them to mobilise politically in defence of their rights. Although the earliest coloured political organisations date back to the 1880s, the first substantive coloured political body, the African Political Organisation (APO),

14 S. Trapido, “The Friends of the Natives": Merchants, Peasants and the Political and Ideological Structure of Liberalism in the Cape', in S. Marks and A. Atmore (eds), Economy and Society in Pre-Industrial South Africa (London, Longman, 1980), p. 266.

15 The most significant were the exclusion of coloured people from the franchise in the former Boer republics after the Anglo-Boer War; the promulgation of the School Board Act of 1905 that segregated the Cape's education system by providing compulsory public schooling for white children only; and the denial of the right of coloured people to be elected to Parliament with the implementation of Union in 1910. Van der Ross, Rise and Decline of Apartheid, pp. 43-55; Lewis, Between the Wire and the Wall, pp. 30-9, 46-63.

16 For example, the 1921 Juvenile Affairs Act set up mechanisms for placing white school leavers in suitable employment, while the Apprenticeship Act of 1922 put such training beyond the reach of most coloured youths by stipulating educational entry levels that very few coloured schools met, but which fell within the minimum standard set for white schools. The 1925 Wage Act subverted the ability of coloured labour to undercut white wage demands by setting high minimum wage levels in key industries. Lewis, Between the Wire and Wall, pp. 131-3, 161-3; S. Patterson, Colour and Culture in South Africa: A Study of the Status of Cape Coloured People of the Union of South Africa (London, Routledge and Kegan Paul, 1953), pp. 71-2; G.V. Doxey, The Industrial Colour Bar in South Africa (Cape Town, Oxford University Press, 1961), pp. 198-9; W.H. Hutt, The Economics of the Colour Bar: A Study of the Economic Origins and Consequences of Racial Segregation in South Africa (London, André Deutsch, 1964), pp. 35-6, 74-5.

17 L. Thompson, The Cape Coloured Franchise (Johannesburg, South African Institute of Race Relations, 1949) pp. 20-1, 55; G. Lewis, 'The Reaction of the Cape "Coloureds" to Segregation' (Ph.D. thesis, Queens University, 1984), pp. 330-1; T. Shifrin, 'New Deal for Coloured People? A Study of National Party Policies Towards the Coloured People' (BA Honours thesis, University of Cape Town, 1962), pp. 20-3.

18 Van der Ross, Rise and Decline of Apartheid, Chapter 16; Lewis, Between the Wire and Wall, pp. 261-2, 26770; du Pré, Separate but Unequal, Chapters 4-8; V. Bickford-Smith, E. van Heyningen and N. Worden, Cape Town in the Twentieth Century: An Illustrated Social History (Cape Town, David Philip, 1999), pp. 143-96. 
was established in Cape Town in $1902 .{ }^{19}$ Under the leadership of the charismatic Dr Abdullah Abdurahman, who served as president from 1905 till his death in 1940, the APO dominated coloured protest politics for nearly four decades. It became the main vehicle for expressing this community's assimilationist aspirations as well as its fears at the rising tide of segregationism until its demise in the mid-1940s.$^{20}$ Intensifying segregation and the failure of the APO's moderate approach contributed to the emergence of a radical movement inspired by Marxist ideology within the better educated, urbanised sector of the coloured community during the 1930s. The National Liberation League (NLL), founded in 1935, and the NonEuropean Unity Movement (NEUM), established in 1943, were the most important of the radical organisations. Prone to fissure and unable to bridge the racial divisions within the society, the radical movement failed in its quest to unite blacks in the struggle against segregation. $^{21}$

The South African Coloured People's Organisation (SACPO), ${ }^{22}$ which was founded in 1953 and affiliated to the ANC-led Congress Alliance, also organised protests and demonstrations, especially against the removal of coloured people from the voters' roll. ${ }^{23}$ Organised opposition to apartheid from within the coloured community was, however, effectively quelled by state repression following the Sharpeville massacre of 1960 and only re-emerged in the wake of the Soweto uprising of 1976. Meanwhile, two political parties the Labour Party of South Africa and the Federal Coloured People's Party - that were prepared to work within apartheid structures, were sanctioned during the heyday of apartheid. $^{24}$

From the latter half of the 1970s onwards, starting with the popularisation of Black Consciousness ideology, the nature of coloured identity became an extremely contentious issue as increasing numbers of educated and politicised people who had been classified 'coloured' under the Population Registration Act rejected the identity. ${ }^{25}$ Colouredness increasingly came to be viewed as an artificial categorisation imposed on society by the ruling minority as part of its divide-and-rule strategies. The growth of a mass, non-racial, democratic movement in the 1980s that burgeoned under the leadership of the United Democratic Front (founded in 1983), as well as controversy over the participation of some coloured leaders in the Tricameral Parliament of the P.W. Botha government from 1984 onwards, fed coloured rejectionist sentiment. With the western Cape an epicentre of resistance to apartheid, the nature of coloured identity became a highly charged issue within

19 Lewis, Between the Wire and the Wall, pp. 10-25; Van der Ross, Rise and Decline of Apartheid, pp. 1-30.

20 A number of ephemeral political organisations such as the United Afrikaner League of the late 1910s and the Afrikaanse Nasionale Bond of the latter half of the 1920s - bodies that were promoted by Cape National Party politicians hoping to win coloured electoral support - failed to subvert the dominance of the APO. M. Adhikari, 'Abdullah Abdurahman, 1872-1940', in They Shaped Our Century: The Most Influential South Africans of the Twentieth Century (Cape Town, Human and Rousseau, 1999), p. 438; Lewis, Between the Wire and the Wall, pp. $124-6,128-33,250-6$.

21 Hommel, Capricorn Blues, pp. 65 ff.; Lewis, Between the Wire and the Wall, pp. 179-98, 207-44; van der Ross, Rise and Decline of Apartheid, pp. 209 ff.; A. Drew, Discordant Comrades: Identities and Loyalties on the South African Left (Aldershot, Ashgate, 2000), pp. 266-70.

22 SACPO was renamed the Coloured People's Congress (CPC) in December 1959.

23 Lewis, Between the Wire and the Wall, pp. 263-71; Hommel, Capricorn Blues, pp. 135-42, 157-9.

24 For a history of the Labour Party as well as information on the Federal Party and the Coloured Representative Council (CRC), see R. du Pré, 'Confrontation, Co-optation and Collaboration: The Response and Reaction of the Labour Party to Government Policy, 1965-1984' (Ph.D. thesis, Rhodes University, 1994) and for a collection of relevant documents, see P. Hugo, Quislings or Realists? A Documentary Study of 'Coloured' Politics in South Africa (Johannesburg, Ravan Press, 1978), Chapters 4 and 5.

25 The role of coloured people in the Black Consciousness movement and its history in the western Cape, neglected topics in South African historiography, are discussed in E. Messina, 'Kleurlinge is ook Swart: Swartbewustheid in die Wes-Kaap tot 1977', Kronos, 20 (1995), pp. 115-40. 
the anti-apartheid movement and any recognition of coloured identity was repudiated as a concession to apartheid thinking. ${ }^{26}$

In spite of this, the salience of coloured identity has endured. During the four-year transition to democratic rule under president F.W. de Klerk, political parties across the ideological spectrum made ever more strident appeals to coloured identity for support. Not only did it once again become politically acceptable to espouse a coloured identity, but postapartheid South Africa has also witnessed a rapid retreat of coloured rejectionism and a concomitant coloured assertiveness. This has been partly due to a desire to project a positive self-image in the face of the pervasive negative racial stereotyping of coloured people and partly as a result of attempts at ethnic mobilisation to take advantage of the newly democratic political environment. The December 1st Movement of the late 1990s and the various Khoisan revivalist movements of the new South Africa are amongst the more prominent manifestations of these developments. ${ }^{27}$ The resurgence of colouredism has, moreover, to a significant extent been due to fear of African majority rule and a perception that, as in the old order, coloureds were once again being marginalised. A common refrain amongst disaffected coloured people has been 'First we were not white enough and now we are not black enough'. Though far from allayed, these fears have in recent years been alleviated by the fading influence of 'swart gevaar' (black peril) tactics in South African politics and by the acclimatisation of people to the new dispensation. ${ }^{28}$

\section{Continuity and Change in Coloured Identity}

The existing literature on the history of the coloured community takes very little, if any, account of the nature of coloured identity and the ways in which it has functioned as a social identity. Two basic approaches can be discerned in this historiography. First, there are those works that assume coloured identity as given and portray it as fixed. These are for the most part studies based on oversimplified, essentialist conceptions of colouredness as a product of miscegenation, and by their very nature pay little attention to coloured identity as a historically specific and socially constructed phenomenon. Second, there are more sophisticated analyses that assume that the identity has undergone change through a process of continuous evolution that may also have included periods of rapid transformation..$^{29}$ Because none of these studies in any substantive way addresses issues relating to the nature of coloured identity - they are all almost exclusively concerned with coloured political organisation, the oppression suffered by coloured people and government policy towards them - assumptions about continuity and change in that identity have never been discussed, let alone problematised or tested. A contributory

26 For a discussion of attitudes toward coloured identity in the anti-apartheid movement, see M. Adhikari, “'You Have the Right to Know": South, 1987-1994', in L. Switzer and M. Adhikari (eds), South Africa's Resistance Press: Alternative Voices in the Last Generation under Apartheid (Athens, OH, Ohio University Press, 2000), pp. $349-54$.

27 For a discussion of Khoisan revivalism, see M. Besten, 'Khoisan Revivalism and the Limits of Theory: A Preliminary Assessment' (unpublished paper, Institute for Historical Research, University of the Western Cape, 2000). For information on the December 1st Movement, which sought to develop a sense of pride in their slave past amongst coloured people, consult Anon., 'December 1st Movement: Retracing the Path of Memory' (unpublished manuscript, African Studies Library, University of Cape Town, 1996).

28 Aspects of coloured identity in the new South Africa are dealt with in W. James, D. Caliguire and K. Cullinan (eds), Now that We are Free: Coloured Communities in a Democratic South Africa (Boulder, CO, Lynne Riener, 1996) and Erasmus, Coloured by History.

29 The works by Ziervogel, Cruse and van der Ross mentioned elsewhere in the article serve as examples of the former, whereas those of Lewis, Goldin, Hommel and du Pré would be examples of the latter. 
reason for this oversight is that historical thinking conventionally assumes ongoing social change.

This article, in contrast, presents a counter-intuitive argument, namely, that coloured identity is better understood, not as having continuously evolved or undergone a series of transformations during the era of white rule, but rather as having maintained a high degree of consistency of expression despite some changes to the identity. This is not meant to imply that coloured identity was fixed or inert or that it lacked fluidity, but that it operated within fairly clearly defined parameters throughout the period under review and that the changes experienced during this time did not fundamentally alter the way in which it functioned as an identity. These changes were more in the nature of the accretion and sloughing-off of elements around a core of enduring characteristics, adding further layers of complexity and subtlety to the ways in which it manifested itself rather than representing the evolution or mutation of the identity itself. Thus, viewed on the eve of the transition to democracy in the early 1990s, coloured identity functioned in very much the same way it did at the time of the inauguration of the Union in 1910 despite radical changes in the social and political landscape. This particular perspective allows clearer insight into the nature of coloured identity and more accurately reflects the social experience of the coloured community under white domination. ${ }^{30}$

In addition to the conventional expression of coloured identity derived from its stable core, it is recognised that there were a number of developments during the twentieth century that influenced processes of coloured self-perception. The emergence of a radical movement in coloured politics from the second half of the 1930s onwards, although very limited in its impact, was significant because it introduced the idea that black unity or a class-based identity amongst the oppressed was possible and initiated some impetus in this direction within the coloured petty bourgeoisie. ${ }^{31}$ From mid-century onwards, apartheid social engineering and the implementation of apartheid policies had the countervailing effect of reifying coloured identity as never before. The latter phases of the apartheid era witnessed a reaction to this tendency with the growing rejection of coloured identity within sections of the community. Coloured rejectionism was fostered by the revival of mass protest against apartheid during the 1980s and an intensifying disapproval of any form of racial thinking within the anti-apartheid movement. ${ }^{32}$ Could it not be argued that the rejectionist movement had a fundamental impact on the nature of coloured identity and the way in which it operated as a social identity? The analysis presented here would suggest not.

Until the late 1970s there was a high degree of consensus both within the coloured community as well as amongst outsiders about who the coloured people were and what the concept of colouredness embodied. The conventional wisdom - that coloured people were a distinct racial group with its own historical trajectory and destiny - was first challenged in the 1930s when radical intellectuals rejected coloured separatism as playing into the hands of the ruling classes who sought to divide the black majority and split the proletariat. The emphasis on 'Non-European' unity within the radical movement during the middle decades of

30 The argument presented in this article is the result of a research project that initially sought to track the evolution of coloured identity through the twentieth century. When the evidence failed to confirm the assumptions based on this orthodox approach, a reconceptualisation of the nature of coloured identity was clearly necessary. See Adhikari, 'Continuity and Change', p. 321.

31 For some examples of the expression of these ideas by ideologues within the radical movement see B. Kies, Background of Segregation (Cape Town, Anti-CAD, 1943); W.P. van Schoor, The Origin and Development of Segregation in South Africa (Cape Town, Teachers' League of South Africa, 1951) and K. Jordaan, 'Jan van Riebeeck: His Place in South African History', Discussion, 1, 5 (1952).

32 For discussion of the denial of coloured identity in the anti-apartheid movement, see I. Van Kessel, 'Grassroots: From Washing Lines to Utopia', and Adhikari, "You Have the Right to Know" , both in Switzer, and Adhikari, Resistance Press, pp. 308-10, 349-54. 
the twentieth century was not so much a rejection of coloured identity as an assertion that racial differences were not in any way intrinsic and that coloured particularism was damaging to the freedom struggle. From the early 1960s, however, there was an explicit rejection of coloured identity within NEUM circles. ${ }^{33}$ This rejectionism remained extremely limited in its impact in that it did not penetrate much beyond a section of the intelligentsia within the coloured elite. It was only towards the latter half of the 1970s, when Black Consciousness ideology took hold within significant sectors of the coloured community, that the rejection of coloured identity found wider support, growing to its zenith in the non-racial democratic movement during the late 1980s.

Even at its height, however, the rejection of coloured identity was never a broadly-based, popular current taken up by the mass of coloured people but was confined to a relatively small but vocal minority of highly politicised people associated with the anti-apartheid movement. ${ }^{34}$ Although coloured rejectionism sprang from such worthy motives as wanting to banish racist thinking and foster unity in the face of the divisions imposed by apartheid, it was generally not a credo held with deep conviction in the sense that proponents actually believed that coloured identity did not exist or have social relevance, even though this may have been proclaimed with gusto from political platforms. To most of those who renounced their identity as coloured, this was an emotionally laden negation of apartheid values and an act of political defiance and not necessarily the result of a profound conversion to a strict nonracism. For many, this renunciation did not operate much beyond the level of political rhetoric and the refusal to countenance racial distinctions was bound to that context of intense political and ideological conflict. For others, such as media activists Rashid Seria and Moegsien Williams, promoting the fiction that coloured identity was an artificial creation of the white supremacist establishment was a pragmatic strategy for mobilising the coloured masses against apartheid. ${ }^{35}$ Contemplating the charade of non-racism in the democratic movement during the 1980s as well as its limited popular impact, South columnist Sylvia Vollenhoven commented:

The politics of a relatively calm Mitchell's Plain is not the politics of a burning Spine Road ... I heard so much talk of nonracialism and saw so little evidence... Through it all there has always been a part of me that felt like the child in the crowd who saw no new clothes, only a fat, foolish, naked emperor. ${ }^{36}$

Coloured rejectionism was never a mass phenomenon, nor was it ever deeply rooted. ${ }^{37}$ This explains why South Africa experienced such a rapid retreat of the rejectionist tide in the early 1990s and a concomitant resurgence in colouredism.

What is the essence of the stable core at the heart of coloured identity and how does one explain continuities in the way in which it operated through the period of white domination?

33 For detailed elaboration on these issues see M. Adhikari, 'Fiercely Non-Racial? Discourses and Politics of Race in the Non-European Unity Movement, 1943-1970', Journal of Southern African Studies, 31, 2 (June 2005), pp. $403-18$.

34 Adhikari, 'South', pp. 354, 367; van Kessel, 'Grassroots', p. 310; Adhikari, 'Continuity and Change', pp. 241-97.

35 Author's interviews with R. Seria, 16 January and 11 October 1998; and with M. Williams, 17 July 1998. Both activists were fully aware of the contradiction of maintaining a non-racial façade and targeting the coloured community for political mobilisation.

36 South, 13 June 1991. Mitchell's Plain was a sprawling, almost exclusively working-class set of coloured housing estates with a population of perhaps half a million at the time. Spine Road, one of its main thoroughfares, was a favoured place for activists to erect barricades of burning tyres; numerous clashes between youths and police took place there.

37 For detailed examination of the coloured rejectionist movement, which draws on analyses of Educational Journal (1956-70), Grassroots (1980-90), South (1987-94) and the Black Consciousness poetry of James Matthews as case studies, see M. Adhikari, Not White Enough, Not Black Enough: Racial Identity in the South African Coloured Community (Athens, OH, Ohio University Press, 2005), Chapter 4. 
This study identifies four key characteristics that formed the foundation to that outworking of colouredness.

\section{Assimilationism - 'White in Mind and Spirit and Achievement'}

One of the essential features at the heart of coloured identity was assimilationism. ${ }^{38}$ This was less an impulse for acculturation than a striving for acknowledgement of the worth of coloured people as individuals and citizens, and inclusion within the dominant society on the principle that it was 'culture' and 'civilisation' rather than colour that mattered. Throughout the twentieth century, one of the strongest imperatives within the coloured community, especially the petty bourgeois elite, was the urge to gain this acceptance. As is so often the case after the mid-1930s, the exception of a small minority of radicals needs to be noted.

Indeed, the late nineteenth-century genesis of coloured identity emanated from a worldview and a political strategy that were profoundly assimilationist, and during the twentieth century, despite criticism of the racist order, all that the coloured political leadership and the petty bourgeoisie it represented really wanted was for coloureds to be accepted into the dominant society and to share in the benefits of citizenship on the basis of merit. ${ }^{39}$ This was particularly apparent in the manifestos and strategies of coloured communal organisations of the first half of the twentieth century, whether of an overtly political body such as the APO or a professional association such as the Teachers' League of South Africa, formed in 1913 to advance the interests of coloured teachers. ${ }^{40}$ While the predominant current of opinion within the coloured elite aspired to acceptance into English middle-class culture, a significant section also sought accommodation within the fold of Afrikanerdom. ${ }^{41}$ Despite their occasional warning that continued oppression of coloured people could have dire consequences for the society as a whole, the coloured political leadership had no interest in overthrowing the system or changing South African society fundamentally, except for eliminating institutionalised racial discrimination. Fred Hendricks, one of its leading members, gave vent to the frustrated assimilationist urge within the coloured elite in an outburst prompted by mounting segregationism through the 1930s:

...the language of the coloured man is the language of the European; his forebears are Europeans; his mode of living is that of the European and what he has achieved thus far has been in collaboration with the European. Only idle fancy of a warped imagination can visualise for the coloured people of South Africa a set of qualities or ideals entirely distinct from those of the European. $^{42}$

To the coloured community, particularly within the upper strata, western bourgeois culture represented the apogee of human achievement and people's degree of conformity with its values and practices was seen to provide an objective measure of their social development and individual accomplishment. Coloured leaders and communal organisations thus tended to lay stress on their affiliations with whiteness and the

38 Admittedly, it may appear paradoxical to argue that wanting to associate with whiteness was a key feature of being coloured.

39 Adhikari, Teachers' League, pp. 14-17, 22-3, 150. Of course, educated Africans often likewise shared this assimilationist hope.

40 Adhikari, Not White Enough, pp. 72-8, 82-3, 92-4.

41 H. Giliomee, 'The Non-Racial Franchise and Afrikaner and Coloured Identities, 1910-1994', African Affairs, 94, 375 (1995), pp. 199-225; Lewis, Between the Wire and the Wall, pp. 126-30.

42 Educational Journal, April 1939. 
dominant society and strove to demonstrate the extent to which they lived up to the norms of white middle-class respectability, what one dissenting coloured observer referred to as the 'white-mindedness' of the coloured community. ${ }^{43}$ This strong emotional attachment to whiteness was a product not only of the belief that western culture was superior but also of the assumption that their acculturation legitimated coloured peoples' claims to full citizenship rights. Demonstrating their advanced levels of 'culture' and 'civilisation' was seen as their ultimate ticket for inclusion into the body politic as well as social acceptance into the dominant society. ${ }^{44}$ It is thus not surprising that the Educational Journal, the mouthpiece of the Teachers' League of South Africa, the leading professional association within the coloured community in the first half of the twentieth century, could endorse the idea that the surest route for social advancement was 'by being white in mind and spirit and achievement'. ${ }^{45}$

This assimilationism, which has sometimes been misconstrued as the mere rationalisations of self-seeking sycophants and collaborationists, was rooted in a Weltanschauung informed by nineteenth-century Cape liberal values and environmentalist conceptions of racial difference. ${ }^{46}$ For much of the twentieth century, moderate coloured political opinion continued to cling to a progressionist world-view imbued with these ideals. The key assumptions of this utopian outlook were first, that humanity was on a path of inevitable progress towards the ultimate attainment of an Elysian future of social harmony and prosperity. Second, it was assumed that all people, no matter what their current condition, were capable of self-improvement and the attainment of 'civilisation', which in the minds of the coloured elite equated to western bourgeois culture. These assumptions were reinforced by deeply held religious beliefs that not only posited the equality of all humans in the eyes of God but also fed the progressionist vision with ideas about the ultimate redemption of humankind and about its destiny being directed by the guiding hand of a just God. ${ }^{47}$

These assimilationist hopes were remarkably resilient and underlay the longer-term vision of the coloured communal leadership regarding the future of their people and the destiny of humanity in general. The coloured elite continued to nurture hopes of acceptance into the dominant society even as new obstacles were placed in their way and as the prospect of achieving these aspirations deteriorated with the continued tightening of segregationist measures through most of the twentieth century. Although disconcerted by each new discriminatory regulation and alarmed by the more Draconian developments, setbacks were usually rationalised as temporary reversals and acceptance into white middle-class society was often seen as something that coloured people still needed to earn and would only be

43 F. Blume, 'The Education of Coloured Children in the Urban Area of Kimberley' (B.Ed. thesis, University of Cape Town, 1942), pp. 98-100.

44 For two detailed case studies confirming the prevalence of these views within the coloured community, see Adhikari, 'Continuity and Change', pp. 121-79. See also M. Adhikari, “"A Drink-Sodden Race of Bestial Degenerates": Perceptions of Race and Class in the Educational Journal, 1915-1940', in E. van Heyningen (ed.), Studies in the History of Cape Town, 7 (Cape Town, UCT Press in association with the Centre for African Studies, University of Cape Town, 1994), pp. 109-32.

45 Educational Journal, December 1917.

46 In contrast to the pseudo-scientific racist theories that from the latter part of the nineteenth century propagated the idea that racial differences, especially in intellectual capacity, were immutable, earlier explanations based on environmental variation generally accepted that changes in the environment would affect both individuals and social groups, even to the extent of eliminating cultural and intellectual disparities. For evidence of moderate coloured opinion adhering to environmentalist conceptions of racial difference, see $A P O, 12$ February 1910, and Educational Journal, June 1918, August, 1938; for further elaboration on this point see Adhikari, Not White Enough, pp. 76, 90-1.

47 For some examples of this discourse, see John Tobin's speech reported in South African News, 28 November 2003, as well as APO, 24 May 1909, 18 December 1909; Adhikari, Teachers' League, pp. 14-15, 179-80. 
attained after a struggle worthy of the prize. ${ }^{48}$ Indeed, this often served as justification for clinging to their assimilationist hopes in the face of intensifying segregation. Not even the utter rejection of any form of assimilation with the implementation of apartheid measures entirely extinguished these dreams. This desire for assimilation into the dominant society was evident in its most acute form amongst those individuals who were not only willing to disown their identity as coloured and turn their backs on friends, family and former lives, but were also prepared to take the risk of exposure in an attempt to pass for white. ${ }^{49}$ The durability of these yearnings for acceptance to a significant degree explains the eager response of so many coloured people to National Party overtures in the 1994 general election. ${ }^{50}$

With the benefit of hindsight, it is clear that these dreams of assimilation were badly misplaced and out of step with the social and political realities of white supremacist South Africa. This optimism might have had a degree of compatibility with nineteenth-century Cape liberalism or have resonated with western liberal or left opinion in the twentieth century. Indeed, in the first decade of the twentieth century, hopes that individual coloured people would be accepted into white middle-class society on the basis of personal merit and that the community as a whole might in time assimilate into the mainstream of Cape society, though increasingly remote, were not entirely unrealistic. These desires were, however, completely out of place after 1910, in the unified South African state whose policies were increasingly informed by Social Darwinist and segregationist assumptions.

\section{Intermediate Status - 'Less than White but Better than Black'}

The coloured elite and the political leadership could, however, not avoid coming to terms in some way with the reality of the intensifying segregationism that confronted them from the late nineteenth century onwards. Because they were denied their first choice of assimilation into the dominant society, politicised coloureds had little alternative but to mobilise along racial lines to defend their rights and promote their interests as a group. This brings to the fore a second fundamental attribute of coloured identity in South Africa, namely, its intermediate status in the South African racial hierarchy.

Coloured people experienced the South African racial hierarchy as a three-tiered system in which they held an intermediate position between the dominant white minority and the numerically preponderant African majority. As sociologist Zimitri Erasmus put it; 'For me, growing up coloured meant knowing that I was not only not white, but less than white: not

48 For some examples see APO, 31 July 1909; 3 December 1910; Educational Journal, May 1915, December 1917, November 1920, August 1922; A. Desmore, With the Second Cape Corps Through Central Africa (Cape Town, Citadel, 1920), p. 5; J.H. Rhoda, 'A Contribution Toward the Study of Education Among the Cape Coloured People' (B.Ed. thesis, University of Cape Town, 1929), pp. 2ff., 59. For further discussion of this issue, see Adhikari, Teachers' League, pp. 17, 47-8, 157-60. The radical minority was clearly an exception.

49 See G. Watson, Passing for White (London, Tavistock, 1970) and B. Unterhalter, 'Changing Attitudes to "Passing for White" in an Urban Coloured Community', Social Dynamics, 1, 1 (1975), pp. 53-62, for case studies of the phenomenon.

50 Analyses of coloured voting patterns in the 1994 election underplay the significance of deeper historical currents and emphasise short-term, pragmatic considerations. See James et al., Now that We are Free, Chapters 4-7; M. Eldridge and J. Seekings, 'Mandela's Lost Province: The African National Congress and the Western Cape Electorate in the 1994 South African Elections', Journal of Southern African Studies, 22, 4 (1996); A. Reynolds, Election '94: South Africa (Cape Town, David Philip, 1994), pp. 192-3; R. Mattes, H. Giliomee and W. James, 'The Election in the Western Cape', in R.W. Johnson and L. Schlemmer (eds), Launching Democracy in South Africa: The First Open Election, April, 1994 (New Haven, CT, Yale University Press, 1996), pp. 108-67; B. Pickel, Coloured Ethnicity and Identity: A Case Study in the Former Coloured Areas of the Western Cape/South Africa (Hamburg, Lit Verlag, 1997), pp. 84-101. 
only not black but better than black (as we referred to African people) ${ }^{51}$ Radical activist Ben Kies criticised the self-segregating ethos of the Teachers' League similarly in 1943: 'for thirty years they accepted the idea that their children were not fit to be taught with white children and were too good to be taught with African children'; while in the early 1960s, novelist Alex La Guma had one of his race-conscious coloured characters feel 'sorry that he wasn't white and glad he wasn't black'. ${ }^{52}$

The symbolism of referring to coloured people as 'brown' neatly captures this intermediate status. The equation of coloured people with the colour brown is even more entrenched in the Afrikaans language, in which words such as 'bruinman', (brown man) and 'bruinmens' (brown person) are translated as '(Cape) Coloured man' and '(Cape) Coloured person'. ${ }^{53}$ Indeed, writing in 1960, leading Afrikaner literary figure N.P. van Wyk Louw declared the conventional Afrikaans word for coloured, 'kleurling', to be a 'nare woord' (nauseating word) and that he preferred 'bruinmens'. ${ }^{54}$ That coloured intellectual Christian Ziervogel entitled his late 1930s book on the coloured people Brown South Africa; that coloured poet and educationist S.V. Petersen in a 1956 address to the Stellenbosch Afrikaanse Studentebond protested that he was not a 'kleurling' but a 'bruin man'; that coloured political leader Peter Marais in the post-apartheid environment characterised himself as a 'bruin Afrikaner' (brown Afrikaner); and that similar usage of bruin is common in Cape Vernacular Afrikaans; are all sufficient indications that coloured people have, on the whole, accepted this description of themselves. ${ }^{55}$

Because their assimilationist aspirations were thwarted and their intermediate position gave coloured people significant privileges relative to Africans, the basic dynamic behind the assertion of coloured identity and the main thrust of mobilising politically as coloured people was to defend this position of relative privilege. For coloureds, their minority status and political powerlessness, as well as intensifying segregationism, engendered fears that they might end up losing that position and be relegated to the status of Africans. These fears reinforced coloured exclusivity and encouraged a separatist strategy with respect to Africans within the coloured political leadership. ${ }^{56}$ Thus, for example, despite having great sympathy for the plight of Africans, whom he recognised as suffering more severe racial prejudice than coloureds, Abdurahman in 1910 nevertheless made it clear that his duty as president of the APO was to defend the rights 'of the coloured people as distinguished from the native races' ${ }^{57}$ Similarly, the Teachers' League effectively excluded Africans from membership of the organisation and in 1920 spurned a group of African teachers who wished to affiliate as a

51 Erasmus, Coloured by History, p. 13. Emphasis in the original.

52 Kies, Background of Segregation, p. 5; A. La Guma, A Walk in the Night and Other Stories (London, Heinemann, 1967), p. 114

53 See D.B. Bosman, I.W. van der Merwe, L.W. Hiemstra, Tweetalige Woordeboek: Afrikaans-Engels/EngelsAfrikaans (Cape Town, Tafelberg, 1967), pp. 117, 1088; P. Grobbelaar (ed.), Readers' Digest AfrikaansEngelse Woordeboek (Cape Town, Readers' Digest Association of South Africa, 1987), pp. 88-9; J. Branford and W. Branford, A Dictionary of South African English (Cape Town, Oxford University Press, 1991), pp. 51 2; P. Silva (managing ed.), A Dictionary of South African English on Historical Principles (Oxford, Oxford University Press, 1996), pp. 115-16.

54 N.P. van Wyk Louw, 'Voorwoord', in D.P. Botha, Die Opkoms van ons Derde Stand (Cape Town, Human and Rousseau, 1960), p. vi. The suffix '-ling' carries connotations of objectification and emotional distancing. 'Kleurling' was also the official term as used in apartheid legislation and by the bureaucracy that implemented it. Hence the aversion to it of van Wyk Louw, Petersen and others.

55 C. Ziervogel, Brown South Africa (Cape Town, Maskew Miller, 1938); Torch, 19 June 1956; James et al., Now that We are Free, pp. 60-1; G.L. Stone, 'An Ethnographic and Socio-Semantic Analysis of Lexis Among Working-Class, Afrikaans-Speaking, Coloured Adolescents and Young Adult Males in the Cape Peninsula, 1963-1990' (MA thesis, University of Cape Town, 1991), pp. 389-90.

56 C. Ziervogel, The Coloured People and the Race Problem (Ceres, Weber, 1936), p. 5; Adhikari, Teachers' League, pp. 13-14, 17-18, 149-50, 162-4.

57 APO, 9 April 1910. 
separate branch with the justification that 'the view held by the League is that our body stand for the coloured teacher ${ }^{58}{ }^{58}$ Only a small minority of coloured people, opposed to this strategy in principle, chose the alternatives of communism or black unity or a combination of the two.

Coloured assimilationism together with the insecurities engendered by their intermediate status meant that the most consistent, and insistent, element in their expression of identity in daily life was an association with whiteness, and a concomitant distancing from Africanness, whether it be in the value placed on a fair skin and straight hair, the prizing of white ancestors in the family lineage or taking pride in their assimilation to western culture. In 1911, acerbic coloured newspaper columnist Piet Uithalder noted the tendency for 'respectable' coloured families to hang portraits of white ancestors in prominent places in their homes while being very reticent about acknowledging black ancestors. ${ }^{59}$ Christian Ziervogel, however, had no compunction about rejecting any association of coloured people with Africans in his 1936 tract, The Coloured People and the Race Problem, and calling on the ruling establishment to 'give the coloured people the benefit of their white blood' ${ }^{60}$ In a 1993 interview, a workingclass coloured woman, Mrs D.E., gave voice to the racist chauvinism that often resulted from this affiliation with whiteness:

En 'n kaffir al dra hy 'n goue ring, bly nog steeds 'n aap.... Hulle het niks, hulle sê hulle het 'n culture, hulle het nie 'n culture nie, hulle's rou. Hulle sê ons bruin mense is mixed masala, maar ons bruin mense staan [nader] aan die wit mense, as wat hulle aan die wit mense ... staan. Want ons culture en die culture van die wit mense se culture is een.

[And a kaffir, even if he wears a golden ring, still remains an ape.... They have nothing, they say they have a culture, they don't have a culture, they're raw. They say we brown people are mixed masala, but we brown people are closer to white people, than they are to white people. Because our culture and the white people's culture are the same. $]^{61}$

Colloquially, this deference to whiteness has often been attributed to the coloured or slave mentality.

In spite of the racially egalitarian rhetoric that characterised so much of the discourse of coloured protest politics, it has to be recognised that coloured political organisations were, on the whole, racially exclusive and strove to entrench the relative privilege coloured people enjoyed. If the ultimate aim of much of coloured political organisation was that of acceptance into the dominant society, then most of its day-to-day politicking was a narrow concern with the advancement of coloured interests. Thus, whereas there was an assertion of non-racial values and protest against discrimination, there was also an accommodation with the racist order and an attempt to manipulate it in favour of coloured people. ${ }^{62}$ Organisations such as the APO, the Afrikaanse Nasionale Bond and the Coloured People's National Union exemplified this stance in the first half of the twentieth century, while the Labour Party and the Federal Coloured People's Party did so in the latter half. ${ }^{63}$

That there was ambivalence about their identity within the coloured community, especially within the petty bourgeoisie, should not come as a great surprise. While their

58 Educational Journal, December 1920; APO, 30 October 1920.

59 APO, 17 June 1911; M. Adhikari, Straatpraatjes: Language, Politics and Popular Culture in Cape Town (Pretoria, van Schaik, 1997), p. 97.

60 Ziervogel, The Coloured People and the Race Problem, pp. 5, 6.

61 S. Field, 'Fragile Identities: Memory, Emotion and Coloured Residents of Windermere', in Erasmus, Coloured by History, p. 105. The references to the ape with the golden ring echoes the well-known Afrikaans proverb 'Al dra ' $n$ aap ' $n$ goue ring, bly hy steeds 'n lelike ding' (Though an ape may wear a golden ring, he remains an ugly thing).

62 Organisations within the radical tradition are obvious exceptions. Although, for example, the Anti-CAD was effectively, and SACPO exclusively, coloured in membership, their ultimate goals were broadly socialist.

63 Lewis, Between the Wire and the Wall, pp. 126-33, 237-52; du Pré, 'Confrontation, Co-optation and Collaboration', Chapter 4; Hugo, Quislings or Realists, Chapters 4, 5; Adhikari, 'Continuity and Change', pp. $122-45$. 
assimilationism tended to dampen separatist tendencies within the coloured community, their desire to protect their status of privilege relative to Africans pushed coloured people into asserting a distinct identity. And while their being the victims of racism promoted the principle of non-racism, political realities forced them to organise on a racial basis. What is more, organising on a racial basis was, by and large, rewarded by the white supremacist state, especially under apartheid. Coloureds' claim to relative privilege over Africans resonated strongly with the dominant society's perception of what the social order should be, whether perceived as God-given or natural. Privileging coloureds over Africans was also useful as part of a divide-and-rule strategy. The attempt to exploit segregationism to their own advantage confirms John Cell's observation that although 'force lay behind segregation... most of the time segregation was self-enforcing, ${ }^{64}$ The structurally ambiguous position of the coloured community within the South African racial hierarchy thus played an important part in reinforcing and reproducing the identity.

\section{Negative Associations - 'They are the Leftovers'}

The intermediate status of the coloured grouping contributed in two ways to a third key characteristic of coloured identity, namely, that it was largely the bearer of a range of negative and derogatory connotations. Firstly, because of their lack of political and economic clout and because they formed a relatively small stratum within the racial hierarchy, the coloured people tended to be perceived in terms of the larger groups. This was most notable in official definitions of the term 'coloured', in which the category was usually described as consisting of those people who were neither white nor African. ${ }^{65}$ This was, for example, precisely the way in which the reports of both major commissions of enquiry into the coloured community, the Wilcox Commission of the 1930s and the Theron Commission of the 1970s, described coloured people. ${ }^{66}$ The community was thus usually not identified in a positive manner, as social groups generally are, in terms of a set of distinctive characteristics, but was denoted in a negative fashion with reference to other groups, in terms of what it was not - as Erasmus put it, "in terms of "lack" or taint, or in terms of "remainder" or excess which does not fit a classificatory scheme'. ${ }^{67}$

This was one of the more subtle ways in which negative associations came to be attached to the concept of colouredness. It reinforced ideas that the coloured people were not of the same standing as other groups; that their claims to autonomous group status - usually articulated in terms of 'nation', 'people' or 'race' - were deficient or lacked a degree of authenticity. The ultimate statement of this perception came from none other than former first lady Marike de Klerk who, in a 1983 interview with a newspaper reporter, expressed the opinion that;

... they [coloureds] are a negative group. The definition of a coloured in the population register is someone that is not black, and is not white and is also not an Indian, in other words a no-person.

64 J. Cell, The Highest Stage of White Supremacy: The Origins of Segregation in South Africa and the American South (Cambridge, Cambridge University Press, 1982), p. 19.

65 For discussion of official definitions of the term 'coloured', see A.J. Venter, Coloured: A Profile of Two Million South Africans (Cape Town, Human and Rousseau, 1974), pp. 1-2; Lewis, Between the Wire and the Wall, p. 3; Patterson, Colour and Culture, pp. 361-3.

66 U.G.54-1937, Report of the Commission of Enquiry Regarding the Cape Coloured Population of the Union, pp. 7-10; R.P.38/1976, Report of the Commission of Enquiry into Matters Relating to the Coloured Population Group, pp. 275, 277.

67 Erasmus, Coloured by History, p. 17. 
They are the leftovers. They are the people that were left after the nations were sorted out. They are the rest. ${ }^{68}$

These ideas were often internalised by coloured people for, as one working- class informant put it to me in the early $1990 \mathrm{~s}$, 'We coloured people are not a proper nation, we don't have our own culture or land that we can say is our own. The coloured people is like a mixed bredie [stew] made up of all different kinds of people ${ }^{69}$ Comparing the coloured people to a mixed bredie is a common Cape Town colloquialism. ${ }^{70}$ The perception that the community lacked cultural distinctiveness or full ethnic integrity not only reinforced their marginality but also the idea that, as the product of miscegenation, coloured people were misfits, somehow inherently deficient - 'God's stepchildren' in Sarah Gertrude Millin's memorable phrase. ${ }^{71}$ Charles Sebe, at the time director of state security in the Ciskei, exemplified these attitudes in his rejection of miscegenation during a speech reported by Joseph Lelyveld, a New York Times journalist: "What will you get from [black/white] in-ter-mar-riage? You get a coloured". The word was pronounced with contempt. "You don't get a white person, you don't get a black person, but a frustrated child which does not belong anywhere", ${ }^{72}$

A second, and related, way in which the intermediate status of the coloured people contributed to these negative perceptions is that it served as a residual category into which smaller groups that did not fit into either the white or African categories were placed. This, again, is very much apparent in official practice where, for example, in census figures or in the compilation of statistics in official publications, those groups that were not manifestly white or African were lumped with the coloured category. Thus, groups such as Malays, Griquas, Rehoboth Basters, Namas and even Indians were at times treated as distinct groups and sometimes included under the rubric of 'coloured'. ${ }^{73}$ The Population Registration Act went to the ridiculous lengths of creating a category labelled 'Other Coloured' for those people who did not fit into any of the other six sub-categories into which the Act had divided those classified coloured. $^{74}$

Because of the negative associations attached to it, colouredness was not enthusiastically embraced in a positive affirmation of self and group identity except in relatively rare or transient instances. The derogations were far too many and too deeply entrenched - both by outsiders, especially whites, and, more importantly, by many coloured people themselves for the identity to function in a positive, affirmative fashion. Coloured identity tended, rather, to be accepted with resignation and often with a sense of shame by its bearers as a bad draw in the lottery of life. ${ }^{75}$

68 Quoted in B. McLennan, Apartheid: The Lighter Side (Cape Town, Chameleon Press, 1990), p. 59.

69 Unrecorded conversation with a middle-aged coloured man translated from Cape Vernacular Afrikaans.

70 For another example of this metaphor see Z. Erasmus, 'Some Kind of White, Some Kind of Black', in B. Hesse (ed.), Un/settled Multiculturalisms (London, Zed Books, 2000), p. 199. See also K. Jachoutek, 'Mixed Bredie in the Creole Cuisine: Cultural Drivers in the Search for "Coloured" Identity at the Cape' (unpublished paper, University of Cape Town, 2003).

71 S.G. Millin, God's Stepchildren (Cape Town, AD Donker, 1924).

72 J. Lelyveld, Move Your Shadow: South Africa, Black and White (London, Michael Joseph, 1985), pp. 173-4. Emphasis in the original. In a written assignment on coloured identity, an African undergraduate student at UCT confirmed that in her Kroonstad township community coloured people were colloquially referred to as 'ma 0.5 ', echoing the common term 'half-caste' (unpublished paper, in possession of the author).

73 See Patterson, Colour and Culture, p. 199; Lewis, Between the Wire and the Wall, pp. 9-10, 128, 131; Venter, Two Million South Africans, pp. 2, 14.

74 For a brief description of this act and its various amendments see M. Horrell, Legislation and Race Relations: A Summary of the Main South African Laws which Affect Race Relations (Johannesburg, South African Institute of Race Relations, 1971), pp. 9-12.

75 For further discussion of colouredness associated with shame, see Z. Wicomb, 'Shame and Identity: The Case of the Coloured in South Africa', in D. Attridge and R. Jolly (eds), Writing South Africa: Literature, Apartheid and Democracy, 1970-1995 (Cambridge, Cambridge University Press, 1998), pp. 91-107. 
Erasmus lists some of the negative associations attached to coloured identity as 'immorality, sexual promiscuity, illegitimacy, impurity and untrustworthiness' ${ }^{76}$ One could add others to the list such as propensities to criminality, gangsterism, drug and alcohol abuse, and vulgar behaviour. ${ }^{77}$ The most pervasive of the negative characteristics attached to colouredness, however, and one that is usually seen as the source of other weaknesses, was the idea that this status was a product of miscegenation. The implications to a popular mindset suffused with Social Darwinist assumptions were that coloured people were automatically deficient in those positive qualities derived from racial purity and knee-haltered by those negative ones that emanate from racial mixture. Having internalised the racist values of the dominant society and having accepted racial mixture as the defining characteristic of their identity, coloured people by and large viewed their community as indelibly stigmatised by their supposed condition of racial hybridity. This has been an extremely onerous burden to bear, especially within the coloured petty bourgeoisie and 'respectable' but poorer sectors of the community, in a society increasingly obsessed with racial purity and the dangers of 'mongrelisation'. In its very first issue the $A P O$, for instance, lamented that while coloured people were recognised as 'a product of civilisation' they were nevertheless deemed to represent 'its most repellent manifestation'. ${ }^{78}$ Reflecting on her own upbringing in a 'respectable' coloured family, Zimitri Erasmus comments, 'I can see how respectability and shame are key defining terms of middle class coloured experience' ${ }^{79}$

In this regard the coloured community was trapped in a catch-22 situation partly of its own making. In order to distance themselves from Africans and protect their status of relative privilege, coloureds emphasised their partial descent from European colonists. But it was precisely this claim that encumbered them with the stigma of racial hybridity. The import of white supremacist discourse about the South African past was that the coloured people were the unwanted and unfortunate consequence of the colonisation of southern Africa ${ }^{80}$ Writing at the end of the 1930s, historian J.S. Marais confirmed that white South Africa's 'philosophy of blood and race ... [was its] primary article of faith' and had led to 'a passionate aversion to miscegenation' ${ }^{81}$ The coloured people were thus a source of embarrassment to the white supremacist establishment as reminders of past lapses in morality. As the Reverend Alan Boesak inimitably put it:

We were there looking them in the eye and saying to them, 'Well here we are. So what about your pure race theory and what about your chosen-people-of-God theory?' We were the living proof that [they were] not really able to lock up every human emotion. ${ }^{82}$

76 Erasmus, Coloured by History, p. 17.

77 A UCT student, as part of a third-year History research project, did a word-association exercise in which people were asked to respond spontaneously and instantly to his utterance of the word 'coloured'. Virtually all of the responses were negative, the most common of which was 'Gam' (Ham), the stereotype for the loud, uncouth, working-class coloured person. See S. Ariefdien, 'Coloured Identity and Politics in the Western Cape from the APO to the 1994 Elections' (unpublished paper, University of Cape Town, 2003). For further information on the Gam stereotype, see Adhikari, 'Sons of Ham' and 'Continuity and Change', p. 58.

78 APO, 24 May 1909. See also M. Adhikari, “"The Product of Civilisation in its Most Repellent Manifestation": Ambiguities in the Racial Perceptions of the APO, 1909-1923', Journal of African History, 38, 2 (1997), pp. $283-300$.

79 Erasmus, Coloured by History, p. 13. Although voiced in the context of the added dimension of the gendered stereotyping of coloured women, the quote nevertheless holds true generally.

80 For a typical example of this sort of discourse, see H.P. Cruse, Die Opheffing van die Kleurlingbevolking: Deel I: Aanvangsjare, 1652-1795 (Stellenbosch, Christen Studentevereniging, 1947). See also C. Hendricks, "Ominous" Liaisons: Tracing the Interface Between "Race" and "Sex" at the Cape', in Erasmus, Coloured by History, p. 35.

81 J.S. Marais, The Cape Coloured People, 1652-1937 (Johannesburg, Witwatersrand University Press, 1968), p. 282. This book was first published by Longmans Green \& Co. in 1939.

82 S. Ariefdien interview with A. Boesak, September 2003. 
From the white supremacist point of view, the coloured people also presented a continuing danger because of the threat of ongoing miscegenation. The spectre of racial degeneration prompted anxieties that, in the long run, white supremacy and the survival of western civilisation in southern Africa might well be at stake. In the mid-1920s, Sarah Gertrude Millin quoted Smuts as cautioning that "white South Africans (must) have a care lest one day... "little brown children play among the ruins of the Union Government Buildings". ${ }^{83}$ The promulgation of the immorality acts and the Mixed Marriages Act confirms the reality of these fears.

The burden of this negative baggage was compounded by the inability of organic intellectuals within the community to delineate a positive set of symbols, a distinctive culture or an acceptable myth of origin around which those who regarded themselves as coloured could cohere with a sense of pride. Their slave past and Khoisan heritage were generally treated as embarrassments requiring a tactful silence rather than as positive symbols for rallying the group. ${ }^{84}$ While their assimilation to western culture was emphasised because of their determination to distance themselves from Africans, organic intellectuals within the group were sensitive to the general perception that the coloured people did not have a distinctive culture. To illustrate with a recent anecdote: when asked afterwards why he had been visibly moved by the experience of visiting the museum at the Genadendal mission station, a prominent coloured politician from the Western Cape replied that he had always been under the impression that coloured people did not have a culture but that the history of Genadendal had proved otherwise to him. ${ }^{85}$

What is more, those cultural features commonly accepted as distinctively coloured have generally been denigrated and accorded low status in South African society. The Afrikaans vernacular distinctive of the coloured community and variously referred to as Cape, Capey, Gamtaal (language of Ham) or Kombuis (kitchen) Afrikaans has, for example, customarily been stigmatised as a mark of social inferiority. Until relatively recently, when the argument that Afrikaans is a Creole language gained popularity, ${ }^{86}$ there was widespread acceptance within the coloured community of white, especially Afrikaner, denigration of kombuis Afrikaans as a vulgar patois. As early as 1910 the APO thus urged coloured people to 'endeavour to perfect themselves in English ... [and] drop the habit of expressing themselves in the barbarous Cape Dutch', which it described as being fit only for the kitchen, ${ }^{87}$ while the Educational Journal in 1918 noted that there were too many coloured teachers who were ashamed of their moedertaal (mother tongue) ${ }^{88}$ More recently, a middleclass coloured informant in the mid-1990s told me that although kombuis Afrikaans was his home language, he felt ashamed of using it when speaking to whites or 'respectable people' as

83 S.G. Millin, The South Africans (London, Constable \& Co., 1926), p. 276.

84 See A. Smith, 'The Hotnot Syndrome: Myth-Making in South African School Textbooks', Social Dynamics, 9, 2 (1983), as well as R. van der Ross, Up From Slavery: Slaves at the Cape - Their Origins, Treatment and Contribution (Cape Town, Ampersand Press, 2005), p. iii; Adhikari, 'Continuity and Change', pp. 55-59.

85 This incident was related to me by a confidant of the politician who accompanied him on the tour some time during the course of 2000. The informant wishes to remain anonymous.

86 For a sense of popular debate around the issue, see 'Painful Discovery of a Rejected Moedertaal' and 'Boere Don't Own Afrikaans', in Cape Times, 30 October 1996. For academic works in which this argument is made, see A. Davids, 'Words the Cape Slaves Made: A Socio-Linguistic Study', South African Journal of Linguistics, 8 (1990), pp. 1-24; H. den Besten, 'From Khoekhoe Foreigner Talk via Hottentot Dutch to Afrikaans: The Creation of a Novel Grammar', in M. Putz and R. Derven (eds), Wheels within Wheels: Papers of the Duisburg Symposium on Pidgin and Creole Languages (New York, P. Lang, 1989), pp. 207-49; P. Roberge, 'The Formation of Afrikaans', in R. Mestrie (ed.), Language and Social History: Studies in South African SocioLinguistics (Cape Town, David Philip, 1995), pp. 68-88.

87 APO, 13 August 1910. See also APO, 8 April 1911, 10 August 1912; E. Maurice, 'The Development of Policy in Regard to the Education of Coloured Pupils at the Cape, 1880-1940' (PhD thesis, University of Cape Town, 1966), pp. 332-34; Adhikari, Not White Enough, pp. 69-70.

88 Educational Journal, June 1918; Adhikari, Teachers' League, pp. 102-3. 
it would mark him as 'low class' ${ }^{89}$ An Afrikaner school inspector in the mid-1970s exemplified white attitudes toward the dialect when, upon hearing me speak the vernacular to some of my high school students, admonished me in a gentle but paternalistic tone for using 'daardie gebasterde taal' (that bastardised language) and perpetuating uncultured practices amongst my students. ${ }^{90}$ The Coon Carnival, a celebration of the new year particular to the coloured community - though embraced by most working-class coloured people as their own and more recently touted as an example of colourful Cape culture to promote tourism - was similarly stigmatised amongst whites and middle-class coloureds as boorish, disreputable and even depraved. ${ }^{91}$

The lack of positive identification with colouredness meant that much of the social mobilisation and political activity done in the name of the coloured people was in reaction to white racism rather than a pro-active marshalling of ethnic resources. Throughout the era of white domination, anger, anxiety and fear engendered by social injustices suffered by coloured people, rather than a positive identification with colouredness, proved to be the more potent means for mobilising people on the basis of their identity as coloured. Rather than voicing an affirmation of colouredness, coping with white racism motivated such separatist agendas. Virtually all coloured communal organisations, whether cultural, professional or political, were formed because coloureds were excluded from the corresponding white bodies, or were established in response to one or other segregationist development. ${ }^{92}$

Coloured exclusiveness was, in this sense, fundamentally reactive in nature, being shaped by the need to contend with white racism and the state's segregationist policies. Coloured exclusiveness tended, on the one hand, to involve a reluctant separation from whiteness and, on the other, a firm distancing from Africanness. As indicated earlier, the basic impetus behind this response was to protect coloureds' position of privilege relative to Africans and to try and keep hopes of future acceptance into the dominant society alive. This tended to reinforce existing racial boundaries despite the non-racial rhetoric that usually accompanied coloured protest politics. The pervasive power of these racial identities was such in South Africa that even in the most obvious exception to the pattern of racially exclusive political organisation, the Non-European Unity Movement, the outcome of 15 years of an uneasy cross-racial alliance was a split largely along racial lines in $1958 .^{93}$

\section{Marginality - 'We are the Jam'}

The essentially reactive nature of coloured exclusivity, especially in response to segregationism, points to the marginality of the coloured people. This, the fourth of the key attributes, had a greater direct impact than the others on the functioning of coloured identity

89 Author's unrecorded casual conversation with a coloured businessman.

90 The year was 1976 and I was teaching at Bonteheuwel High School in the working-class suburb of Bonteheuwel, Cape Town. The name of the inspector has long since escaped me. A common subtext to comments of this sort is that it is not unexpected that a 'bastardised' people would speak a 'bastardised' language.

91 Cape Standard, 9 January 1940, 16 January 1940; Torch, 5 January 1948, 25 March 1952; Muslim News, 29 November 1968; Cape Herald, 20 December 1969; D.C. Martin, Coon Carnival: New Year in Cape Town, Past and Present (Cape Town, David Philip, 1999), pp. 117-19, 126-30; S. Jeppie, 'Popular Culture and Carnival in Cape Town: The 1940s and 1950s', in S. Jeppie and C. Soudien (eds), The Struggle for District Six: Past and Present (Cape Town, Buchu Books, 1990), p. 74; L. Baxter, 'History, Identity and Meaning: Cape Town's Coon Carnival in the 1960s and 1970s' (MA thesis, UCT, 1996), pp. 157, 172, 181-82.

92 For detailed case studies confirming this, see Adhikari, 'Continuity and Change', especially Chapter 3.

93 A. Drew, 'Social Mobilisation and Racial Capitalism in South Africa' (Ph.D. thesis, University of California, 1991), pp. 476-7; van der Ross, Rise and Decline of Apartheid, pp. 211-15. 
because it was the most important determinant of the day-to-day conditions under which it had to operate. The coloured community's response to its predicament of marginality is central to the manner in which the identity manifested itself socially and politically. The marginality of the coloured people goes a long way towards explaining how coloured people perceived themselves as a social group, the contradictions and ambiguities within the identity as well as the changes it experienced through the twentieth century. It was also the source of a great deal of frustration and anger as well as a degree of fatalism within the coloured community. ${ }^{94}$

The coloured community was a marginal group in that it never formed more than about 9 per cent of the South African population throughout the twentieth century. ${ }^{95}$ Although constituting a significant minority, it did not enjoy anything like a commensurate level of influence or power under white supremacy. A heritage of slavery, dispossession and racial oppression ensured that coloured people lacked any significant economic or political power as a group and that by far the greater majority consisted of a downtrodden proletariat. Under white minority rule, the coloured community had no meaningful leverage to bring about change in the society, to reform it or to influence the way in which it was governed. Indeed, the coloured communal and political leadership had great difficulty drawing attention to their standpoint and having their protestations taken seriously by the powers that be. Coloured political organisations were doomed to be bit-players on the political stage and coloured protest politics was little more than a sideshow in the national arena. Even in the western Cape where the majority of coloured people were concentrated and actually formed a majority of the population, ${ }^{96}$ their political influence progressively declined through the greater part of the century. ${ }^{97}$ Other coloured communal organisations were small, isolated and similarly powerless. This impotence was highlighted early on when the APO, despite remarkable success in mobilising coloured opinion behind the protest campaign against the Act of Union, was unable to change a single clause in the Draft South Africa Act. ${ }^{98}$ In subsequent decades, coloured protest politics was unable to boast a single clear-cut victory in the battle against white supremacy. The clearest demonstration of the community's powerlessness came with the removal of coloured people from the common voters' roll in 1956, notwithstanding mass protests and support from liberal whites.

The marginality of the coloured community meant that it had little choice in the matter of accepting an inferior social status to whites or the second-class citizenship imposed upon it by the state. Marginality to a large extent accounts for the pragmatism and opportunism of much of coloured protest politics as well as the incrementalism that characterised its strategies. ${ }^{99}$ These characteristics were especially marked in the more moderate organisations such as the APO, the TLSA (Teachers' League of South Africa), the Afrikaner Nasionale Bond and, in the latter part of the twentieth century, the Labour Party. Grappling with their predicament of marginality also goes some way toward explaining key developments in the history of the coloured community such as the emergence of a radical movement in the mid-1930s, the spread of the rejectionist movement in coloured identity from the late 1970s onwards and the resurgence of colouredism at the end of the twentieth century. For, whatever else may

94 For a study of marginality within the coloured community of Durban, see H.F. Dickie-Clark, The Marginal Situation: A Sociological Study of a Coloured Group (New York, Routledge and Kegan Paul, 1996).

95 Compare figures provided in Statistics South Africa, 2000, 1.4, which summarises basic population census data from 1904 onwards.

96 According to South African Census, 1996, p. 6, 59.6 per cent of coloured people lived in the Western Cape and formed a majority of 54.2 per cent of the population in the province.

97 Thompson, Coloured Franchise, p. 55; Patterson, Colour and Culture, pp. 35-36; Shifrin, 'New Deal for Coloured People', p. 58.

98 Lewis, Between the Wire and the Wall, pp. 46-63; Adhikari, Teachers' League, pp. $23-4$.

99 For further confirmation of this, see Adhikari, 'Continuity and Change', especially Chapter 3; Lawrence, 'Search for Identity', Chapter 6. 
have gone into their making, frustration engendered by powerlessness played a part in the adoption of these new political strategies.

Trapped by their condition of marginality, the coloured community found its options for social and political action severely constrained. Their assimilationist overtures spurned by whites, and joint organisation with the African majority either not a practical or attractive option, the coloured community was left isolated and politically impotent. To the majority of the political and communal leadership the only realistic option open to them was to bow to white power and adopt an incrementalist political approach that would in time lead to the coloured community's acceptance into the dominant society. Perceiving the demand of full equality with whites to be an exercise in futility, coloured leaders and organisations for the most part instead set out to play the racial system to the minimum disadvantage of coloureds. This resulted in an outlook that was highly opportunistic and a political strategy that took every opportunity to reinforce coloureds' status of relative privilege. Although often rationalised as a necessary and temporary ploy, this acceptance of their second-class status could lead to a profound sense of helplessness as demonstrated by the abject submissiveness Stephen Reagon, senior vice-president of the APO, articulated in 1938, 'Despite all the things we suffer and need, we are not unmindful, we are grateful for the crumbs which have fallen from the [white man's] table'. ${ }^{100}$

The radical movement in coloured politics was an obvious exception to this compliant outlook. The NLL, NEUM and SACPO initiatives were, however, too narrowly based and ephemeral to have broken this exclusivity or to have had much of a popular impact. It was only relatively late in the century, when a significant sector within the coloured community broke categorically with the separatist agenda and embraced non-racialism as part of a populist agenda, that individuals such as Alan Boesak, Trevor Manuel and Patricia de Lille, from within its ranks, started having a notable impact on national politics and the broader society. Even then, in the 1990s, the majority of coloured people felt vulnerable and alienated from the African majority, preferring to ally themselves with their former oppressors, as the 1994 elections emphatically demonstrated. Their insecurity is captured in the colloquial expression, 'we are the jam', which likens coloured people to the thin layer of jam squeezed between two slices of bread. The metaphor gives expression to both their marginality as well as their intermediate status in the racial hierarchy. This expression, usually uttered in a resigned tone of voice and used to express alienation and political apathy or to justify support of the National Party, became especially popular during the uncertain times facing the coloured community in the mid-1990s. ${ }^{101}$

\section{Conclusion}

This article has argued, against the grain of conventional historical thinking, that it would be truer to reality and more productive to view coloured identity as having remained stable throughout the era of white domination rather than as having experienced a series of transformations or having evolved during this period. It has sought to substantiate this thesis by demonstrating that this stability was derived from a core of enduring characteristics of

100 Sun, 13 May 1938.

101 This expression appears to be a version of the more conventional 'ham in the sandwich' which is also meant to convey the idea of something being caught between two more powerful forces. It is appropriate that relatively expensive ham is substituted with jam, a staple in many working-class coloured homes. In my experience this expression was also taken up by conservative Indians fearful of majority rule. See the quotation attributed to an anonymous Indian person in J. Crwys-Williams, The Penguin Dictionary of South African Quotations (Sandton, Penguin, 1999), p. 134. 
the identity rooted in the historical experience and social situation of the coloured community. It has also shown how the structurally ambiguous position of coloured people in the South African racial hierarchy and their internalisation of the racist values of the dominant society served to reproduce the identity within predictable parameters. Defending the coloured community's status of privilege relative to Africans played a particularly powerful role in stabilising the identity. Coloured marginality has, in addition, been pinpointed as the most significant of these characteristics, as it determined the basic conditions under which the identity had to operate and coloured people had to function as bearers of the identity.

The stability of coloured identity under white supremacy is accentuated by a new creativity in some of the ways it has been adapting to the radically different environment of post-apartheid South Africa. ${ }^{102}$ The new South Africa has represented a time of flux and of unprecedented change in the way colouredness has operated and, indeed, needs to operate, as a social identity. Most importantly, that bulwark of coloured exclusivity, the protection of a relatively privileged status, is simply no longer a valid strategy in the new dispensation, though some organic intellectuals within the coloured community have been trying to establish a new form of relative privilege by presenting coloured people as the true indigenes of the country, even arguing for first nation status. The advent of democracy has meant that inter-group relations have become much more complex and fluid than before. With complexity has come confusion as well as opportunity. Importantly, democracy brought with it a significant increase in the political clout of the coloured community as its voting strength became commensurate with its demographic profile and allowed for full participation of coloured people in the political process, both as individuals and as representatives of particular interest groups. The new democratic environment has thus brought with it a degree of freedom of association and opportunities for ethnic mobilisation not possible under white rule. Witness, for example, the attempts at re-inventing coloured identity within the Khoisan revivalist movement and of shifting political alliances with white interest groups that have been formed around opposition parties.

Despite apartheid-era social relations having been undermined by the change in government, the adoption of one of the most progressive constitutions in the world, the emergence of an African middle class and politically acceptable discourse centring on multicultural values and the imperatives of nation building, South Africa is still very much a society fractured by race. With the racial hierarchy intact in many areas of South African life and with racist attitudes and racial modes of thinking prevalent at a popular level, it is not surprising that the old coloured identity that prevailed in white supremacist South Africa is still very much alive, though somewhat chastened, often manifesting itself in the form of an anti-African bigotry and a reactionary appraisal amongst many, especially within the working classes, that 'we were better off under the white man'. It needs to be stressed, however, that this is a defensive racism that arises from the coloured community's position of weakness and feelings of vulnerability and that there is some material basis to this disaffection. ${ }^{103}$

MOHAMed AdHIKARI

Department of Historical Studies, University of Cape Town, Rondebosch, Cape Town, South Africa 7700.E-mail:mad@humanities.uct.ac.za

102 For an analysis of coloured identity in post-apartheid South Africa see M. Adhikari, 'Not Black Enough: Reflections on Changing Expressions of Coloured Identity in Post-Apartheid South Africa', South African Historical Journal, 51 (2004), pp. 167-78.

103 See Adhikari, 'Not Black Enough', pp. 171-3 for further elaboration on this last point. 